\title{
Temporary use of a coastal ecosystem by the fish, Pomadasys corvinaeformis (Perciformes: Haemulidae), at Guaratuba Bay, Brazil ${ }^{1}$
}

\author{
Paulo T. C. Chaves ${ }^{2} \&$ Carlos E. Corrêa ${ }^{2}$ \\ Universidade Federal do Paraná, Departamento de Zoologia \\ (Caixa Postal 19020, 81531-990, Curitiba, PR, Brasil). \\ poissons@cce.ufpr.br
}

- Abstract: Pomadasys corvinaeformis is one of the most abundant species found in Guaratuba Bay, an Atlantic coastal, estuarine ecosystem in Paraná, Brazil. We tested whether this species comprises a resident or migratorial population. Abundance, size distribution, and gonad development of individuals captured during the year show that pre-adults enter the system when salinities are greater (autumn and early winter). During this time, they are mostly associated with mangroves and adjacent areas. When salinities begin to fall (late spring and summer) these now maturing individuals return to the sea where they spawn. Thus, $P$. corvinaeformis is migratorial and estuarine-dependent and uses this area prior to sexual maturity. During the period in this bay, $P$. convinaeformis presents a great plasticity of feeding habits, that include mainly Crustacea, Mollusca and Thaliacea.

- Resumo: Pomadasys corvinaeformis é uma das espécies de maior representatividade na ictiofauna da Baía de Guaratuba, litoral do Estado do Paraná. Este trabalho investigou se a espécie compõe ali uma população permanente, residente no sistema, ou se é migratória, freqüentando-o apenas em épocas determinadas. Resultados de 12 meses sobre variações de abundância, distribuição de tamanho e aspectos reprodutivos indicam que indivíduos subadultos ingressam no sistema quando a salinidade é maior (outono, começo de inverno). Nesta época, os indivíduos utilizam a área de manguezal e suas adjacências. Quanto a salinidade começa a cair (final de primavera, verăa), esstes indivíduos agora em maturação gonadal retornam para o mar, onde desovam. P. corvinaeformis é, portanto, uma espécie migratória e estuarino-dependente que utiliza a Baỉa em período anterior ao de maturidade gonadal. Ali, apresenta uma dieta muito variada, constituída basicamente de Crustacea, Mollusca e Thaliacea.

- Descriptors: Migration, Fish, Estuaries, Feeding habits, Haemulidae, Pomadasyidae.

- Descritores: Migração, Peixes, Estuários, Alimentação, Haemulidae, Pomadasyidae.

\section{Introduction}

Most species that inhabit estuarine systems are occasional visitors or migrants through these systems. This tendency for fish to migrate through, rather than reside in, estuarine systems has been attributed to the wide fluctuation in environmental conditions (Amanieu \& Lasserre, 1982). In spite of variable environmental conditions, some migrant

(1) Contr. number 1159 of the Department of Zoology/UFPR, Financial grants: CNPq and FUNPAR/UFPR

(2) Fellowships of CNPq. populations can reach greater abundance and biomass than that of other resident populations. In the mangroves of Guaratuba Bay, southern Brazil ( $\left.28^{\circ} 52^{\prime} \mathrm{S} ; 48^{\circ} 39^{\prime} \mathrm{W}\right)$, some of the most common fish species (Bairdiella ronchus, Isopisthus parvipinnis, three Eucinostomus spp.; Chaves, 1996; Chaves et al, 1998; Chaves \& Otto, 1999) temporarily utilize the estuary as a "nursery area".

One of the most abundant of these species in the area is the roughneck grunt ("corcoroca"), Pomadasys corvinaeformis (Steindachner, 1868) (Haemulidae=Pomadasyidae), a small, schooling species (Chaves \& Bouchereau, 1999). Individuals 
usually occur in Guaratuba Bay within the range of sizes previously reported for this species: juveniles $=40 \mathrm{~mm}$ (Costa et al., 1995) and maximum $=250 \mathrm{~mm}$ (Menezes \& Figueiredo, 1980). Corcoroca have no commercial importance in this region, but they take part in the food dynamic of the fish assemblage. They apparently leave the mangroves during spring and summer (cf. Chaves, 1998), but it is unknown whether they a) remain inside the Bay and spawn, or; b) leave the Bay, moving to the ocean, to spawn. Studies of other populations of this species report its occurrence in estuaries (Araújo et al., 1998) and along coastal oceanic beaches (Costa et al., 1995). Here, spatial and temporal occurrences of $P$. corvinaeformis are examined in the Guaratuba Bay, near the mangroves studied by Chaves (op. cit.). We also examined the dietary habits and compared with work outside of estuaries (Fortaleza beach, Brazil - Costa et al., op. cit.).

\section{Material and methods}

Fish were collected monthly from May 1998 to April 1999 in three areas along an east-west transect of approximately $12 \mathrm{~km}$, from the Guanxuma river (area 1) to the proximity of the sea (area 3) (Fig. 1). We towed an otter trawl with a $20 \mathrm{~mm}$ mesh monthly for seven minutes in waters $3-4 \mathrm{~m}$ (depth) in each area. Bottom water salinity, $\mathrm{pH}$ and temperature (except in June and October) were also measured using a Van Dorn bottle.
Fish specimens were weighed, measured (total length, TL) and dissected to assess reproductive stage and sample stomach contents. Sex and maturation stage were evaluated by visual examination of gonads, using a four stage classification (immature, maturing, mature and spent; Vazzoler, 1996). Next, stomachs with food items were immediately fixed in a $10 \%$ formalin solution for later examination with a stereoscopic microscope. Contents were analyzed in two ways: 1) frequency of occurrence (FO), defined as the proportion of stomachs that contained a given food item, and 2) proportional abundance $(\mathbf{P})$, measured as the number of points covered by each item on a grid of points spaced $4 \mathrm{~mm}$, divided by the total number of points occupied by the contents. Items were ranked using these two methods based on the Preponderance Index (PI; Juras \& Yamaguti, 1985):

$\mathbf{P I}_{\mathrm{i}}=\left(\mathbf{F O}_{\mathrm{i}} \cdot \mathbf{P}_{\mathrm{i}}\right) / \sum_{\mathrm{i}=1 \rightarrow \mathrm{n}}\left(\mathbf{F} \mathbf{O}_{\mathrm{i}} \cdot \mathbf{P}_{\mathrm{i}}\right) \cdot 100$

where " " is each one of the " $n$ " identified items.

All variables used in statistical analysis were tested for normality, and when appropriate, parametric or non-parametric analyses were used. The abiotic characteristics in the three study areas were compared using ANOVA. These were compared monthly and for the entire study period. A five-year recor (1993-1998) of monthly rainfall collected nearby (Morretes IAPAR station, $30 \mathrm{~km}$ from Guaratuba Bay) explains salinity variation in the estuary (Fig. 2). Voucher specimens are deposited in Museu de História Natural Capão da Imbuia collection, Curitiba, Brazil (MNHCI 8260 to 8262).

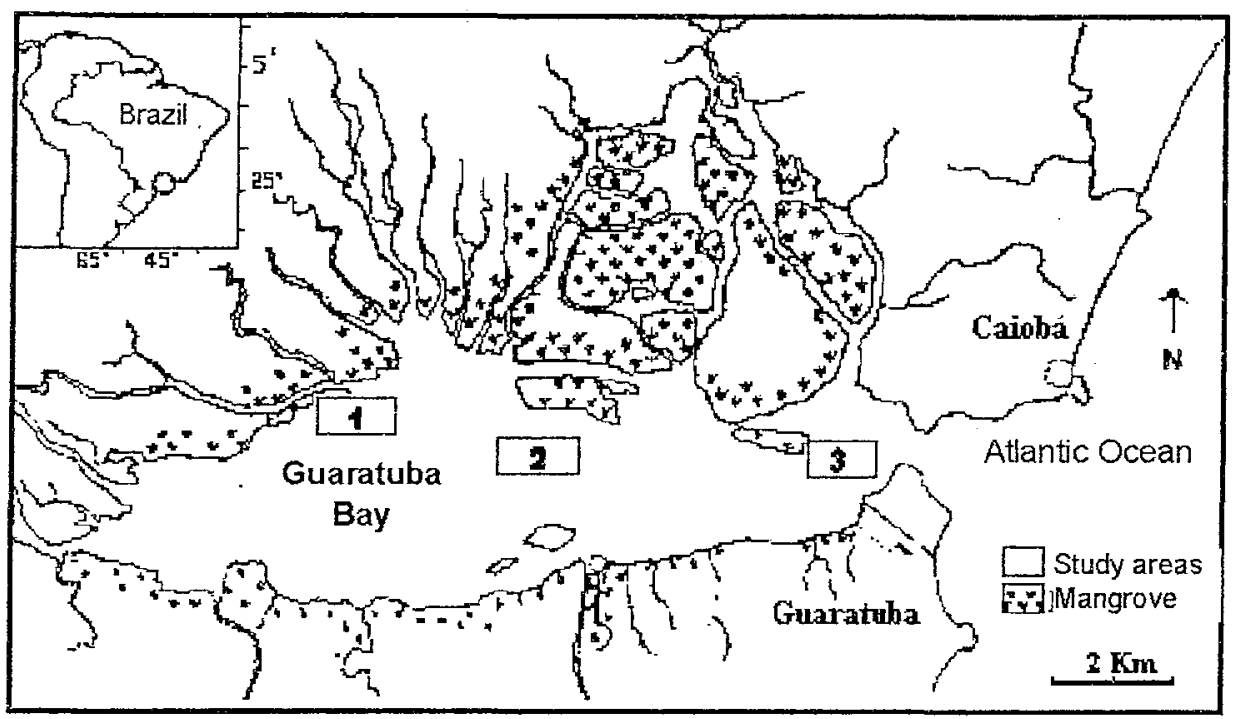

Fig. 1. Map of Guaratuba Bay, Southern Brazil, showing positions of study areas $(1,2,3)$ relative to the sea and rivers entering the bay, as well as the mangrove zone (northern region) studied by Chaves (1998). 


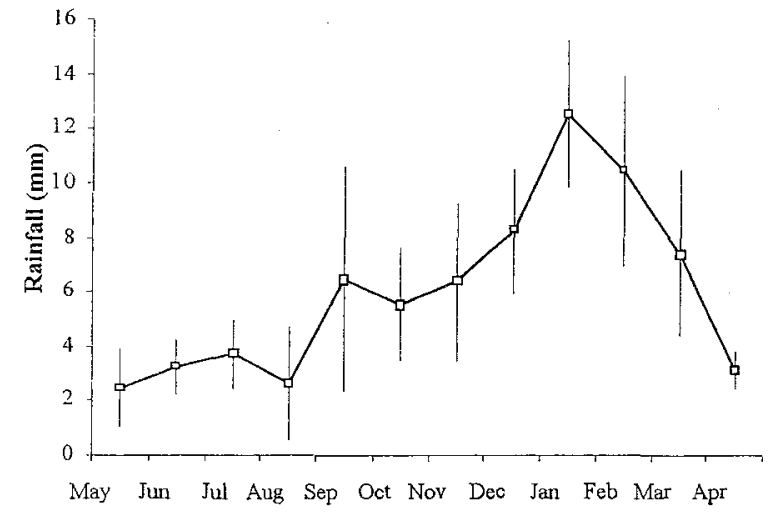

Fig. 2. Rainfall (mean, standard deviation), from measurements taken at Morretes IAPAR (Instituto Ambiental do Paraná) Station, January 1993 to October 1998.

\section{Results}

Salinity, pH, Temperature - Average salinity was significantly greater in area 3 than in areas 1 and 2 $(\mathrm{F}=16.9$; d.f. $=2 ; \mathrm{p}<0.01)$, which had similar salinity levels. January had the lowest salinity levels in all three areas (Tab. 1), and differences between areas were not significant $(F=1.5$; d.f. $=9 ; p>0.05)$. Rainfall was greatest during summer months resulting in the lower salinities (Fig. 2). Area 3 had the greatest average $\mathrm{pH}\left(\mathrm{X}^{2}=10.14 ;\right.$ d.f. $\left.=2 ; \mathrm{p}<0.01\right)$, but no monthly trends in $\mathrm{pH}$ were observed $\left(\mathrm{X}^{2}=15.71\right.$; d.f. $=9 ; p>0.05)$ (Tab. 1). Water temperatures were not statistically different among the areas $\left(X^{2}=0.84\right.$; d.f. $=2 ; \quad p>0.05$ ), but did vary among months $\left(X^{2}=25.9\right.$; d.f. $\left.=9 ; p<0.01\right)$, with highest temperatures during summer (January-March) and lowest during winter (July-September) (Tab. 1).

Fish - A total of 520 individuals were netted, most between June and December (Fig. 3). Mean TL of these fish ranged from a minimum of $66 \mathrm{~mm}$ in February to a maximum of $140 \mathrm{~mm}$ in December (Fig. 4a). The largest individuals were found at the highest temperatures and the lowest salinities (Figs 4b,c). No "corcoroca" were netted in January, March, April or May. During the other months, they were only netted in area 3 , nearest of the sea, except December, when they were also taken in area $2(\mathrm{n}=64 ; 111 \leq \mathrm{TL} \leq 140 \mathrm{~mm}$, the largest of the two areas - Fig. $4 \mathrm{~d})$.

Reproductive data - Sex ratio was $48 \%$ male : $52 \%$ female for 406 specimens. Fish in the "maturing" phase $(\mathrm{n}=27 ; 115 \leq \mathrm{TL} \leq 140 \mathrm{~mm})$ were only found in area 2, in December (Tab. 2). All other specimens $(\mathrm{n}=379 ; 83 \leq \mathrm{TL} \leq 135 \mathrm{~mm}$ ) were immature, and were found in areas 2 and 3. "Mature" or "spent" phase individuals were never captured.

Stomach contents - All specimens collected in February had empty stomachs. Thus, stomach contents are only compared for specimens $(n=256)$ collected between June and December. The monthly abundance in the diet for the most common items, based on Preponderance Index values, varied widely (Fig. 5). Thaliacea, Gastropoda, Amphipoda, Copepoda and plants were the most common food items (Tab. 3). Polychaeta, Crustacea larvae and Diatomacea were also common, presenting frequency of occurrence greater than $10 \%$ and proportional abundance greater than $4 \%$.

Table 1. Bottom salinity, pH and temperature values by month and sampling area (1 to 3) in Guaratuba Bay, during survey period. X: mean; $\mathrm{S}$ : standard error.

\begin{tabular}{|c|c|c|c|c|c|c|c|c|c|c|c|c|c|c|c|}
\hline & \multicolumn{5}{|c|}{ SALINITY (\%o) } & \multicolumn{5}{|c|}{$\mathrm{pH}$} & \multicolumn{5}{|c|}{ TEMPERATURE $\left({ }^{\circ} \mathrm{C}\right)$} \\
\hline AREA & 1 & 2 & 3 & $\mathrm{X}$ & $\mathbf{S}$ & 1 & 2 & 3 & $\mathbf{X}$ & $\mathbf{S}$ & 1 & 2 & 3 & $\mathbf{X}$ & $\mathbf{S}$ \\
\hline May/98 & 12.1 & 18.1 & 22.2 & 17.5 & 5.1 & 7.8 & 8.1 & 8.2 & 8.0 & 0.2 & 23.0 & 23.0 & 24.0 & 23.3 & 0.6 \\
\hline July & 7.8 & 11.6 & 21.5 & 13.6 & 7.1 & 7.4 & 8.1 & 8.7 & 8.1 & 0.6 & 20.0 & 20.0 & 20.0 & 20.0 & 0.0 \\
\hline August & 19.3 & 19.3 & 23.2 & 20.6 & 2.2 & 7.0 & 7.1 & 7.1 & 7.1 & 0.1 & 20.0 & 21.0 & 20.0 & 20.3 & 0.6 \\
\hline September & 12.0 & 12.0 & 18.0 & 14.0 & 3.5 & 7.7 & 7.9 & 8.1 & 7.9 & 0.2 & 20.0 & 21.0 & 20.0 & 20.3 & 0.6 \\
\hline November & 2.0 & 4.0 & 30.0 & 12.0 & 15.6 & 7.4 & 7.5 & 8.5 & 7.8 & 0.6 & 20.0 & 21.0 & 21.0 & 20.7 & 0.6 \\
\hline December & 5.0 & 11.0 & 26.0 & 14.0 & 10.8 & 7.4 & 8.0 & 8.4 & 7.9 & 0.5 & 26.0 & 26.0 & 25.0 & 25.7 & 0.6 \\
\hline January/99 & 0.0 & 0.0 & 16.0 & 5.3 & 9.2 & 5.9 & 5.7 & 7.8 & 6.5 & 1.2 & 25.0 & 25.0 & 28.0 & 26.0 & 1.7 \\
\hline February & 0.0 & 4.0 & 18.0 & 7.3 & 9.4 & 6.8 & 7.1 & 8.0 & 7.3 & 0.6 & 27.0 & 28.0 & 28.0 & 27.7 & 0.6 \\
\hline March & 4.0 & 6.0 & 30.0 & 13.3 & 14.5 & 6.0 & 6.4 & 7.5 & 6.6 & 0.8 & 26.0 & 26.0 & 28.0 & 26.7 & 1.1 \\
\hline April & 5.0 & 6.0 & 20.0 & 10.3 & 8.4 & 7.8 & 7.8 & 8.4 & 8.0 & 0.3 & 20.0 & 21.0 & 22.0 & 21.0 & 1.0 \\
\hline $\mathbf{X}$ & 6.7 & 9.2 & 21.5 & & & 7.2 & 7.4 & 8.1 & & & 23.0 & 23.2 & 23.6 & & \\
\hline$S$ & 6.2 & 6.3 & 4.2 & & & 0.7 & 0.8 & 0.5 & & & 3.0 & 2.8 & 3.5 & & \\
\hline
\end{tabular}




\section{Discussion}

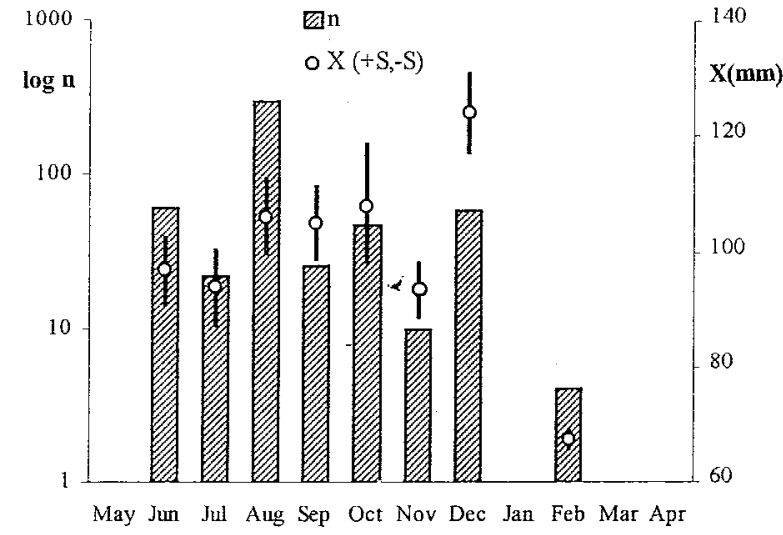

Fig. 3. Number (n), average length $(\mathrm{X})$ and standard error (S) of individuals caught monthly during the study period in Guaratuba Bay.
Because we never found mature or spent fish and corcoroca were primarily netted from June to December, we conclude that $P$. corvinaeformis comprises a migratory population at Guaratuba Bay. During their time of inhabiting the bay, they are most common in two regions: the mangrove (Chaves, 1998) and the estuarine zone near the entrance to the sea (present results). In the mangroves, generally, larger individuals are found than in the second one. Abiotical parameters vary between the study areas and so perhaps the population distribution can be explained by the continental and marine influences that occur in each area. Salinity is minimal when rainfall is maximal (January) in the tributaries feeding into the bay (late spring and summer). This corresponds to the time when $P$. corvinaeformis leaves the Bay and goes to the sea. Conversely, when

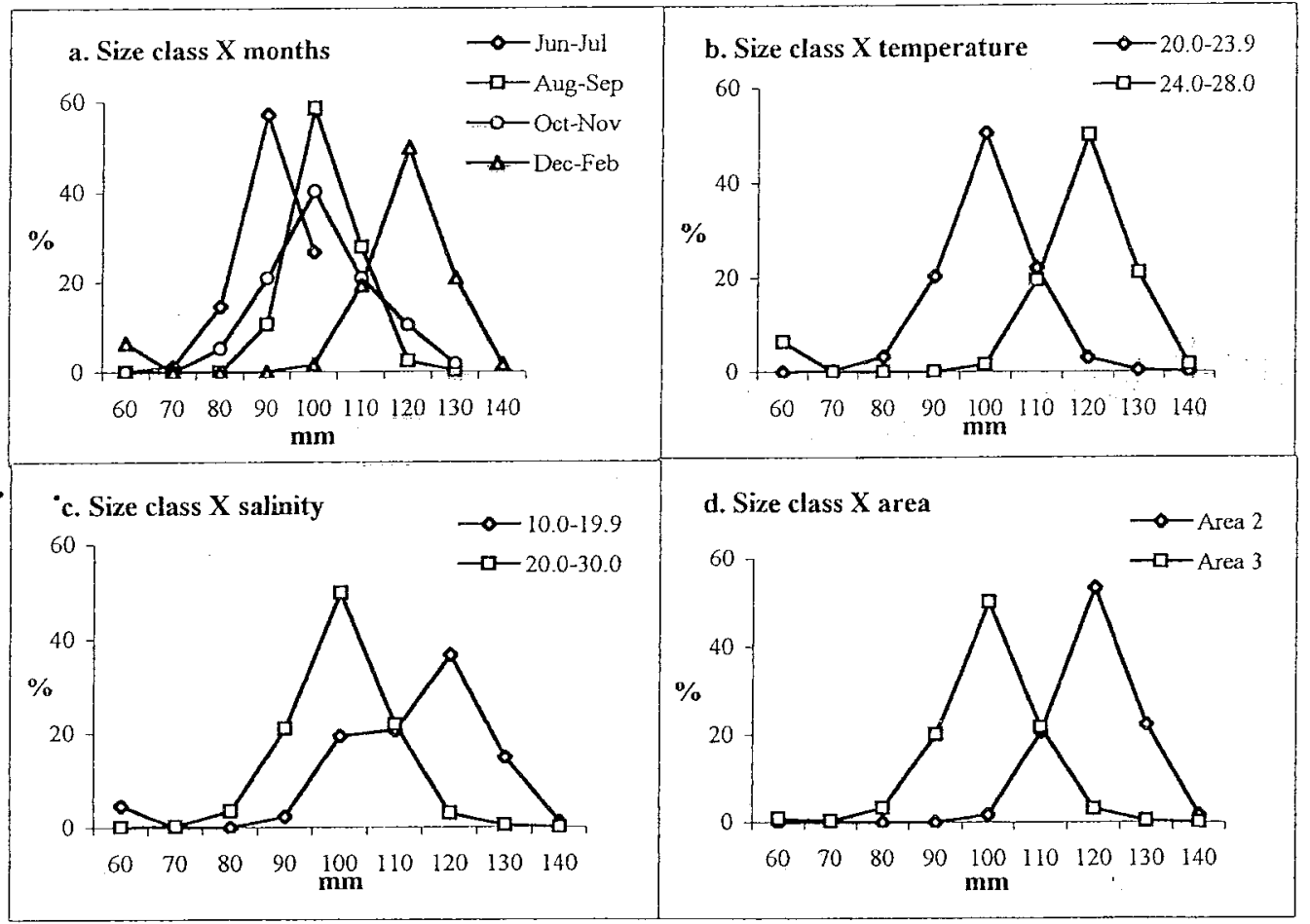

Fig. 4. Size class distributions of individuals $(n=520)$ according to the: a) months of sampling; $b$ ) temperature $\left({ }^{\circ} \mathrm{C}\right)$; c) salinity of the bottom water; and d) study area.

Table 2. Percentage of immature and maturing $P$. corvinaeformis individuals in each month. December: area 2; other months: area 3; n: number of observations.

\begin{tabular}{lrcc}
\hline & n & $\begin{array}{c}\text { Immature } \\
(\%)\end{array}$ & $\begin{array}{c}\text { Maturing } \\
(\%)\end{array}$ \\
\hline June & 8 & 100 & 0 \\
July & 5 & 100 & 0 \\
August & 267 & 100 & 0 \\
September & 26 & 100 & 0 \\
October & 37 & 100 & 0 \\
November & 10 & 100 & 0 \\
December & 53 & 48 & 52 \\
\hline
\end{tabular}




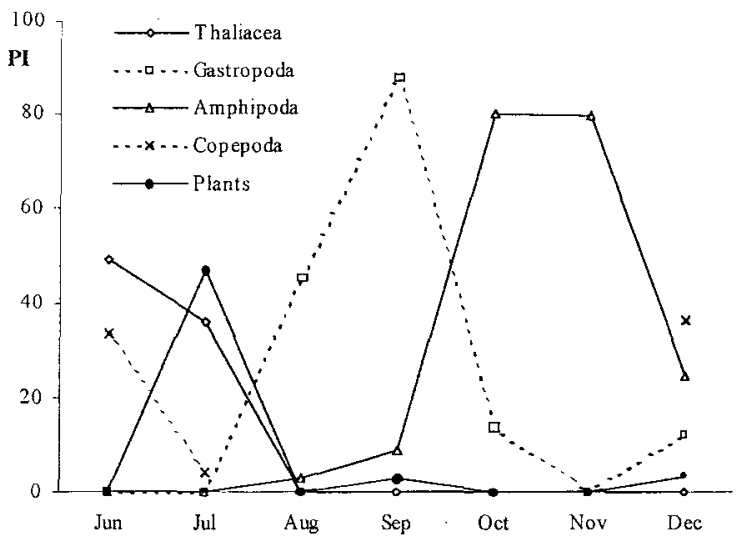

Fig. 5. Preponderance Index values distribution of the main food items of $P$. corvinaeformis in Guaratuba Bay, between June and December 1998. Size and number of specimens are in Table 3.

the rainfall is minimal (autumn/early winter), salinity is higher due to the increased marine influence in the bay. During this time, the pre-adults (and probably also juveniles) enter the estuary. This suggests that Guaratuba Bay is used during growth of individuals and acts as nursery area, as has been shown for other estuarine systems (Yáñez-Arancibia et al., 1993). Earliest phases were not collected, probably because small, planktonic individuals are not netted at these depths and with the mesh size used. However, even during this time of suitable conditions for the fish, individuals never reach the inner areas of the Bay, but rather stay in and near area 3 (and very rarely to area 2), where marine conditions (greater salinity) is greatest. $P$. corvinaeformis does not appear to tolerate lower salinities. Another Pomadasys species, $P$, commersonnii, also does not tolerate lower salinities, due to variation in the water conductivity associated with $\mathrm{pH}$ levels rather than avoidance of elevated flows (Ter-Morshuizen et al., 1996). $P$. corvinaeformis is most abundant along coastal areas of north-west Brazil (Fortaleza) during the rainy season, when salinities are low (Costa et al., 1995). Conversely, inside Guaratuba Bay during similar conditions of high rainfall, the population size is minimal or non-existent. Thus, $P$. corvinaeformis enters the bay during periods of higher salinities and leaves the bay when salinities decline. Appearance in Guaratuba Bay (Fig. 6), therefore, seems to be influenced primarily by salinity.

Table 3. Preponderance Index of the stomach contents (except sand and non-identified material) of $P$. corvinaeformis by month, between June and December 1998. n: number of observations; TL: total length. Mysidacea and Non-Brachyura Decapoda were combined.

\begin{tabular}{|c|c|c|c|c|c|c|c|}
\hline & $\begin{array}{c}\text { Jun } \\
\mathrm{n}=57 \\
86 \leq \mathrm{TL} \\
\leq 108 \mathrm{~mm}\end{array}$ & $\begin{array}{c}\text { Jul } \\
\mathrm{n}=17 \\
78 \leq \mathrm{TL} \\
\leq 100 \mathrm{~mm}\end{array}$ & $\begin{array}{c}\text { Aug } \\
\mathrm{n}=64 \\
91 \leq \mathrm{TL} \\
\leq 126 \mathrm{~mm}\end{array}$ & $\begin{array}{c}\text { Sep } \\
\mathrm{n}=20 \\
95 \leq \mathrm{TL} \\
\leq 120 \mathrm{~mm}\end{array}$ & $\begin{array}{c}\text { Oct } \\
\mathrm{n}=36 \\
92 \leq \mathrm{TL} \\
\leq 138 \mathrm{~mm}\end{array}$ & $\begin{array}{c}\text { Nov } \\
n=6 \\
88 \leq T L \\
\leq 100 \mathrm{~mm}\end{array}$ & $\begin{array}{c}\text { Dec } \\
\mathrm{n}=56 \\
111 \leq \mathrm{TL} \\
\leq 140 \mathrm{~mm}\end{array}$ \\
\hline Polychaeta & $<0.1$ & 2.1 & 50.4 & & 0.8 & & 0.2 \\
\hline Fish & 1.8 & & 0.2 & & & & 10.8 \\
\hline Copepoda & 33.5 & 4.3 & 0.5 & & & & 36.3 \\
\hline Decapoda Brachyura & & & & & & & 1.4 \\
\hline $\begin{array}{l}\text { Non-Brachyura Deca- } \\
\text { poda and Mysidacea }\end{array}$ & & 3.4 & & & 2.9 & & 4.7 \\
\hline Amphipoda & & & 2.8 & 9.0 & 80.6 & 80.0 & 24.5 \\
\hline Tanaidacea & & & 0.7 & & & & \\
\hline Other Crustacea/larvae & & 2.1 & & & & 20.0 & 5.0 \\
\hline Gastropoda & & & 45.4 & 88.0 & 13.9 & & 12.4 \\
\hline Bivalvia & & & & & 0.4 & & 1.0 \\
\hline Thaliacea & 49.3 & 36.0 & & & & & \\
\hline Vitellogenic eggs & & & & & 1.4 & & \\
\hline Diatomacea Centrales & 4.53 & & & & & & \\
\hline Other Diatomacea & 5.34 & & & & & & \\
\hline Plants & $<0.1$ & 43.9 & & 3.0 & & & 3.5 \\
\hline Nematoids & 5.49 & 8.1 & & & & & \\
\hline
\end{tabular}




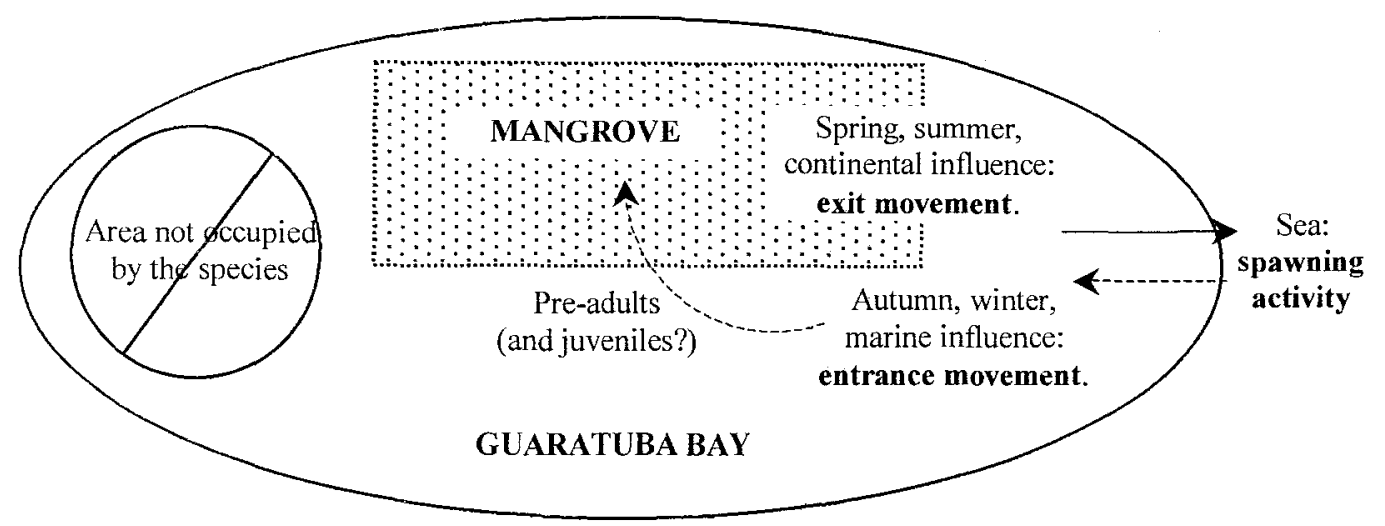

Fig. 6. Model depicting movements of $P$. corvinaeformis in Guaratuba Bay, as suggested by the results presented herein.

Gonad maturation of $P$. corvinaeformis occurs just prior to entry and during exit from the bay. Thus, these fish probably spawn at sea during summer, when salinities are lower in the bay. Another Pomadasys species, $P$. jubelini from the eastern Atlantic, may spawn in estuaries, but also has permanent populations in estuaries as well as in the ocean (Albaret, 1994). Size at first maturation is unknown. In $P$. jubelini from the eastern Atlantic, size at first maturation is estimated at $130 \mathrm{~mm}$ (males) and $160 \mathrm{~mm}$ (females), while all individuals are mature at 150 and $170 \mathrm{~mm}$, respectively (Albaret, 1994). These resuits suggest that individuals found in Guaratuba Bay are probably juveniles and maturing adults. Mature adults are unlikely to return to the bay after spawning.

At Guaratuba Bay, P. corvinaeformis is omnivorous, preferring invertebrates over plants, algae and fish in its diet. At Fortaleza beach, this species eats, in order of abundance, Crustacea, Polychaeta, fish and algae (Costa et al., 1995). Temporal and spatial variations in frequency of each food type are probably associated to food requirements by each size class, implying a plasticity of habits that is associated with migration movements between different regions.

\section{Acknowledgements}

We would like to thank two anonymous reviewers for their suggestions on how to improve the manuscript.

\section{References}

Albaret, J. -J. 1994. Les poissons, biologie et peuplements. In: Durand, J. R., Dufour, P., Guiral, D. \& Zabi, S. G. F. eds. Environnement et ressources aquatiques de Côte-d'Ivoire, Tome II Les milieux lagunaires. Paris, Éditions de l'Orstom. p.239-279.
Amanieu, M. \& Lasserre, G. 1982. Organisation et évolution des peuplements lagunaires. Oceanologica Acta, n. sp: 201-213.

Araújo, F. G.; Cruz-Filho, A. G.; Azevedo, M. C. C. \& Santos, A. C. A. 1998. Estrutura da comunidade de peixes demersais da Baía de Sepetiba, RJ. Rev. Brasil. Biol., 58(3):417-430.

Chaves, P. T. C. 1996. Atividade reprodutiva de Bairdiella ronchus (Cuvier) (Pisces, Sciaenidae) na Baía de Guaratuba, Paraná, Brasil. Revta bras. Zool., 12(4):759-766.

Chaves, P. T. C. 1998. Estrutura populacional de Pomadasys corvinaeformis (Steindachner) (Teleostei, Haemulidae) na Baía de Guaratuba, Paraná, Brasil. Revta bras. Zool., 15(1):203-209.

Chaves, P. T. C. \& Bouchereau, J. -L. 1999. Biodiversité et dynamique des peuplements ichtyiques de la mangrove de Guaratuba, Brésil. Oceanologica Acta, 22(3):353-364.

Chaves, P. T. C. \& Otto, G. 1999. The mangrove as a temporary habitat for fish: the Eucinostomus species at Guaratuba Bay, Brazil

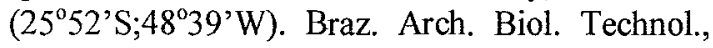
Curitiba, 42(1):61-68.

Chaves, P. T. C.; Rickli, A. \& Bouchereau, J. -L. 1998. Stratégie d'occupation de la mangrove la baie de Guaratuba (Brésil) par le Sciaenidae prédateur Isopisihus parvipinnis (Teleostei, Pisces). Cah. Biol. mar., 39(1):63-71.

Costa, P. S. R.; Santos, M. A. M.; Espínola, M. F. A. \& Monteiro-Neto, C. 1995. Biologia e biometria do coró, Pomadasys corvinaeformis (Steindachner) (Teleostei: Pomadasyidae), em Fortaleza, Ceará, Brasil. Arq. Ciên. Mar, Fortaleza, 29(1-2):20-27. 
Juras, A. A. \& Yamaguti, N. 1985. Food and feeding habits of king weakfish, Macrodon ancylodon (Bloch \& Schneider, 1801) caught in the southern coast of Brazil. Bolm Inst. oceanogr., S Paulo, 33(2):149-157.

Menezes, N. A. \& Figueiredo, J. L. 1980. Manual de peixes marinhos do sudeste do Brasil. IV. Teleostei (3). Universidade de São Paulo, Museu de Zoologia. 96p.

Ter-Morshuizen, L. D.; Whitfield, A. K. \& Paterson, A. W. 1996. Influence of freshwater flow regime on fish assemblages in the Great Fish River and estuary. South. Afr. J. Aquat. Sci., 22(1-2): $52-61$.
Vazzoler, A. E. A. M. 1996. Biologia da reprodução de peixes teleósteos: teoria e prática. Maringá, EDUEM. $169 \mathrm{p}$.

Yáñez-Arancibia, A.; Lara-Dominguez, A. L. \& Day Jr, J. W. 1993. Interactions between mangrove and seagrass habitats mediated by estuarine nekton assemblages: coupling of primary and secondary production. Hydrobiologia, 264(1):1-12.

(Manuscript received 07 July 1999; revised 10 November 1999; accepted 24 April 2000) 